\title{
Hypoxia-Inducible Factor 1: Control of Oxygen Homeostasis in Health and Disease
}

\author{
GREGG L. SEMENZA \\ Institute of Genetic Medicine and Department of Pediatrics, The Johns Hopkins University School of \\ Medicine, Baltimore, Maryland 21287 U.S.A.
}

\begin{abstract}
ABST
Hypoxia-inducible factor 1 (HIF-1) is a transcriptional acti-
vator that mediates changes in gene expression in response to
changes in cellular oxygen concentrations. HIF-1 is a het-
erodimer consisting of an oxygen-regulated HIF-1 $\alpha$ subunit and
a constitutively expressed HIF-1 $\beta$ subunit. In mice, complete
HIF-1 $\alpha$ deficiency results in embryonic lethality at midgestation
because of cardiac and vascular malformations. Analyses of
animal and cell culture models as well as human tissue have
provided evidence that HIF-1 plays important roles in the patho-
physiology of preeclampsia, intrauterine growth retardation, hy-
\end{abstract}
poxia-mediated pulmonary hypertension, and cancer. HIF-1 promotes neovascularization in response to myocardial or retinal ischemia by activating transcription of the gene encoding vascular endothelial growth factor. HIF-1 may also mediate the protective response to cerebral ischemia known as late-phase preconditioning. (Pediatr Res 49: 614-617, 2001)
Abbreviations:
HIF-1, hypoxia-inducible factor 1
VEGF, vascular endothelial growth factor

In humans, complex cardiovascular, hematopoietic, and respiratory systems develop to maintain oxygen homeostasis. Heart disease, cancer, cerebrovascular disease, and chronic obstructive lung disease are the most common causes of mortality in the United States, accounting for two thirds of all deaths annually. In these disorders, disruption of oxygen homeostasis represents a major aspect of disease pathophysiology. HIF-1 is a transcriptional activator that mediates changes in gene expression in response to changes in oxygen concentration. HIF-1 plays important roles in normal development, physiologic responses to hypoxia, and the pathophysiology of common human diseases.

\section{MOLECULAR BIOLOGY}

HIF-1 is a dimeric transcription factor composed of HIF- $1 \alpha$ and HIF-1 $\beta$ subunits $(1,2)$. Under nonhypoxic conditions the HIF- $1 \alpha$ subunit is subjected to ubiquitination and proteasomal degradation (3). In response to hypoxia, ubiquitination and degradation of HIF- $1 \alpha$ are inhibited, resulting in rapid accumulation of the protein (4). In addition, the activity of the

Received August 11, 2000; accepted October 30, 2000.

Correspondence and reprint requests: Gregg L. Semenza, M.D., Ph.D., Johns Hopkins Hospital, CMSC-1004, 600 N. Wolfe St., Baltimore, MD 21287-3914, U.S.A.; e-mail: gsemenza@jhmi.edu

Supported by grants from the American Heart Association National Center and Mid-Atlantic Affiliate, Children's Brain Tumor Foundation, and the National Institutes of Health (R01-DK39869 and R01-HL55338).

Recipient of the Society for Pediatric Research 2000 E. Mead Johnson Award for Research in Pediatrics, presented at the 2000 Annual Meeting of the Pediatric Academic Societies, Boston, MA, U.S.A.
HIF- $1 \alpha$ transactivation domains is induced by hypoxia $(5,6)$. HIF- $1 \alpha$ dimerizes with HIF- $1 \beta$, which is constitutively expressed, resulting in the formation of active HIF-1 protein that binds to the core sequence 5'-RCGTG-3' present in target genes, several dozen of which have been identified thus far (Table 1). New target genes continue to be identified and it is likely that the total number of HIF-1-regulated genes in the human genome is an order of magnitude greater than what is presently known.

\section{DEVELOPMENTAL BIOLOGY AND PHYSIOLOGY}

Analysis of knockout mice has demonstrated that HIF- $1 \alpha$ is required for embryonic development and survival. HIF-1 $\alpha$ deficient mouse embryos arrest in their development by d 9 of gestation (E9.0) and die by E10.5 with severe cardiovascular and neural tube defects and massive cell death, especially in the branchial and cephalic regions (7-9). Mice that are heterozygous for the knockout allele and thus partially HIF-1 $\alpha$ deficient develop normally. However, when these mice are subjected to long-term hypoxia $\left(10 \% \mathrm{O}_{2}\right.$ for $\left.3 \mathrm{wk}\right)$, the development of erythrocytosis and pulmonary vascular remodeling is significantly impaired (10). The impaired development of medial wall hypertrophy in small pulmonary arterioles, which is the hallmark of hypoxia-induced pulmonary hypertension, indicates that HIF- $1 \alpha$ is essential for this process. These results suggest that partial pharmacologic inhibition of HIF-1 activity might provide a means to prevent pulmonary vascular remod- 
Table 1. HIF-1 target genes

\begin{tabular}{lc}
\hline \multicolumn{1}{c}{ Gene product } & References \\
\hline Adenylate kinase 3 & 41 \\
$\alpha_{1 \mathrm{~B}}$-Adrenergic receptor & 42 \\
Adrenomedullin & 43 \\
Aldolase A & 7,9 \\
Aldolase C & 7 \\
Ceruloplasmin & 44 \\
Endothelin-1 & 45 \\
Enolase 1 & 7 \\
Erythropoietin & 46 \\
Glucose transporter 1 & $7,9,41$ \\
Glucose transporter 3 & 7 \\
Glyceraldehyde-3-phosphate dehydrogenase & 7,9 \\
Heme oxygenase-1 & 47 \\
Hexokinase 1 & 7 \\
Hexokinase 2 & 7 \\
IGF-II & 48 \\
IGF binding protein 1 & 40 \\
IGF binding protein 2 & 48 \\
IGF binding protein 3 & 48 \\
Lactate dehydrogenase A & 7,9 \\
Nitric oxide synthase 2 & 49,50 \\
p21 & 11 \\
p35srj & 51 \\
Phosphofructokinase L & 7 \\
Phosphoglycerate kinase 1 & $7,9,11$ \\
Plasminogen activator inhibitor 1 & 52 \\
Prolyl-4-hydroxylase $\alpha(\mathrm{I})$ & 53 \\
Pyruvate kinase M & 7 \\
Transferrin & 54,56 \\
Transferrin receptor & 39 \\
Transforming growth factor $\beta_{3}$ & \\
VEGF & 5,11 \\
VEGF receptor FLT-1 & \\
\hline & \\
\hline
\end{tabular}

eling without causing untoward side effects in at-risk patients with chronic obstructive lung disease.

\section{MYOCARDIAL ISCHEMIA-INDUCED VASCULARIZATION}

HIF- $1 \alpha$ is also essential for angiogenesis in ischemic tissue. When HIF- $1 \alpha$-deficient embryonic stem cells are subjected to hypoxia, expression of mRNA encoding VEGF is not induced $(7,9,11)$. In near-term fetal sheep, myocardial hypoxiaischemia results in the induction of HIF- $1 \alpha$ protein, VEGF mRNA and protein, and increased myocardial vascularization (12). The impaired angiogenic response to ischemia in older animals is caused in part by decreased VEGF production as a result of impaired HIF-1 DNA-binding activity (13-15). Preclinical trials of HIF- $1 \alpha$ gene therapy for ischemia indicate that this strategy for therapeutic angiogenesis is at least as effective as VEGF gene therapy (16).

\section{RETINAL VASCULARIZATION AND ISCHEMIC RETINOPATHY}

Expression of HIF- $1 \alpha$ protein and VEGF mRNA are spatially and temporally correlated during normal retinal development (17). These data are consistent with other studies indicating that hypoxia is an essential stimulus for retinal vascularization (18). In a mouse model of oxygen-induced ischemic retinopathy similar to retinopathy of prematurity, 1-wk-old (P7) mice are exposed to hyperoxia from P7 to P12, which blocks VEGF expression in the retina (19). When the mice are returned to normoxic conditions, retinal ischemia develops, which induces VEGF expression. Analysis of HIF- $1 \alpha$ expression revealed a temporal and spatial correlation with VEGF mRNA expression, both with regard to the hyperoxic repression and ischemic induction (17), indicating that HIF-1-mediated VEGF expression may play a major role in the development of retinopathy of prematurity and other ischemic retinal disorders such as diabetic retinopathy. Retinal neovascularization can be prevented by blocking VEGF (20), suggesting that inhibition of HIF-1 activity may be of therapeutic utility in these conditions.

\section{CEREBRAL ISCHEMIA AND DELAYED PRECONDITIONING}

HIF-1 may also play a role in cerebral ischemia. Cerebral infarction can be induced in P7 rat pups by permanent ligation of the left common carotid artery and exposure to $8 \% \mathrm{O}_{2}$ for $3 \mathrm{~h}$. Seven days later the pups are killed and analyzed, revealing an approximately $40 \%$ reduction in hemispheric weight ipsilateral to the carotid occlusion. In contrast, P7 rats that are subjected to $8 \% \mathrm{O}_{2}$ for $3 \mathrm{~h}$ and then $24 \mathrm{~h}$ later are subjected to carotid occlusion and hypoxia are dramatically protected against cerebral infarction (21), a phenomenon known as delayed (late-phase) preconditioning. The 3-h hypoxic preconditioning exposure was shown to induce HIF- $1 \alpha$ protein expression throughout the brain (22). Analysis of HIF-1 $\alpha$ expression in the brains of $\mathrm{P} 7$ rats subjected to carotid occlusion and hypoxia for $3 \mathrm{~h}$ and then killed immediately revealed induction of HIF- $1 \alpha$ protein expression throughout the hemisphere contralateral to the occlusion, whereas in the ipsilateral hemisphere HIF- $1 \alpha$ expression was decreased in the brain parenchyma and dramatically up-regulated in the cerebral microvasculature (22).

HIF-1 $\alpha$ protein expression, HIF-1 DNA-binding and transcriptional activity, and expression of target genes can also be induced by exposing cultured cells to cobalt chloride or iron chelators such as desferrioxamine $(1,5,23)$. A single injection of cobalt chloride or desferrioxamine induced HIF- $1 \alpha$ expression in the brain and protected against the development of cerebral infarction after carotid occlusion and hypoxia (22). The ability of these agents to induce HIF- $1 \alpha$ expression was correlated with their ability to induce protection (hypoxia $>$ $\mathrm{CoCl}_{2}>$ desferrioxamine). The basis for this protective effect is unknown. HIF-1 has been shown to induce the expression of erythropoietin and VEGF (Table 1), each of which has been shown to function as a neuronal survival factor $(24,25)$. In addition, HIF-1 coordinately regulates the expression of genes encoding at least 13 different glucose transporters and glycolytic enzymes (7). After middle cerebral artery occlusion, there is a spatial and temporal correlation between induction of HIF- $1 \alpha$ mRNA and of mRNAs encoding aldolase A, glucose transporter 1, lactate dehydrogenase A, phosphofructokinase L, and pyruvate kinase $\mathrm{M}$ (Table 1) in the penumbra, which is the viable tissue surrounding the infarction (26). The induction of 
glycolytic metabolism by HIF-1 may contribute to the protective effect of preconditioning with cobalt, desferrioxamine, or hypoxia. Whether the net effect of HIF-1 expression in the ischemic state is to protect against or promote infarction is unclear, as cell-based studies suggest that HIF-1 mediates hypoxia-induced apoptosis (27) via induction of p53 $(11,28$, 29).

\section{CANCER}

In contrast to the potentially protective effect of HIF-1 expression in the context of cerebral and myocardial ischemia, HIF-1 plays an important role in promoting tumor progression (30). Mutations that inactivate tumor suppressor genes or activate oncogenes have, as one of their consequences, upregulation of HIF-1 activity, either through an increase in HIF- $1 \alpha$ protein expression, HIF-1 transcriptional activity, or both (Table 2). Increased HIF-1 activity results in increased expression of target genes with important roles in tumor progression such as induction of tumor vascularization by VEGF (the angiogenic switch) and metabolic adaptation to hypoxia via increased glucose transporter and glycolytic enzyme activity (the Warburg effect). Immunohistochemical analysis of 40 human brain tumors revealed a significant correlation between HIF- $1 \alpha$ protein expression, tumor grade, and tumor vascularization (31). HIF- $1 \alpha$ is overexpressed in the majority of common human cancers, including breast, colon, lung, and prostate carcinoma (32).

The relationship between HIF- $1 \alpha$ and the tumor suppressor p53 is of particular significance. Tumor cells subjected to hypoxia undergo p53-mediated apoptosis, which represents a powerful selection for cells that have sustained mutations that result in p53 loss of function (33). In unstimulated cells p53 is bound by MDM2, a ubiquitin-protein ligase that targets $\mathrm{p} 53$ for degradation by the proteasome $(34,35)$. In response to hypoxia, HIF- $1 \alpha$ is induced and binds to p53, an interaction that protects p53 from degradation (28). Instead, MDM2 targets HIF- $1 \alpha$ for degradation (36). Thus, two major consequences of p53 loss-of-function are the prevention of hypoxia-induced apoptosis and increased expression of HIF- $1 \alpha$. Increased HIF1-mediated $V E G F$ gene transcription results in increased vascularization of p53-nonexpressing as opposed to p53-

Table 2. Alterations in human cancer that increase HIF-1 activity

\begin{tabular}{lc}
\multicolumn{1}{c}{ Function } & References \\
\hline Tumor suppressor loss-of-function & \\
p53 & 32,36 \\
PTEN & 58,59 \\
VHL & 37,38 \\
Oncogene gain-of-function & \\
AKT & 58,59 \\
FRAP (mTOR) & 58 \\
PI-3-kinase & 58,59 \\
RAF/MEK/ERK (MAPK) & 60,61 \\
RAS & 62 \\
SRC & 63 \\
Autocrine growth factor stimulation & \\
EGF & 48,58 \\
FGF2 & 48 \\
IGF-1/IGF-2/IGF-1R & $48,64,65$ \\
\hline
\end{tabular}

expressing tumors (36). The von Hippel-Lindau tumor suppressor is also a ubiquitin-protein ligase that specifically targets HIF- $1 \alpha$ for degradation under nonhypoxic conditions $(37,38)$. Von Hippel-Lindau loss-of-function in renal cell carcinomas and cerebellar hemangioblastomas results in constitutive overexpression of HIF- $1 \alpha$ protein and VEGF mRNA, resulting in tumors that are among the most highly vascularized human cancers $(31,32,37,38)$.

\section{CONCLUSION}

HIF-1 is a master regulator of oxygen homeostasis, which is a fundamental requirement for survival. It orchestrates a multitude of biologic processes starting in early embryonic development and extending into adult life. Recent data suggest that HIF-1 may play an important role in the pathophysiology of preeclampsia (39) and intrauterine fetal growth retardation (40). In diseases that represent the most common causes of mortality in western societies (ischemic cardiovascular disease, cancer, and chronic lung disease), there is growing evidence suggesting that modulation of HIF-1 activity, using a pharmacologic or DNA-based approach, may have therapeutic effects.

Acknowledgments. Work from my laboratory cited above was performed by a talented group of postdoctoral fellows (Guang Wang, Bing-Hua Jiang, Narayan Iyer, Faton Agani, Aimee Yu, Carrie Hayes Sutter, and Lori Kotch) and research technicians (Sandra Leung, Rick Roe, Erik Laughner, David Feldser, and Kelly Chiles) to whom I am enormously endebted. This work was also facilitated by collaborations with a group of outstanding investigators both at Johns Hopkins (Dmitri Artemov, Atul Bedi, Zaver Bhujwalla, Peter Campochiaro, Angelo De Marzo, John Gearhart, Ann Lawler, Rajani Ravi, Larissa Shimoda, Jonathan Simons, J.T. Sylvester, Charles Wiener, and Hua Zhong) and elsewhere (Marcelle Bergeron, Peter Buechler, Lowell Davis, Maria-Magdelena Georgescu, Jeff Gidday, David Hilton, Roger Hohimer, Jeff Isner, Rajiv Ratan, Joanne Scalzitti, Frank Sharp, and David Zagzag).

\section{REFERENCES}

1. Wang GL, Jiang B-H, Rue EA, Semenza GL 1995 Hypoxia-inducible factor 1 is a basic-helix-loop-helix-PAS heterodimer regulated by cellular $\mathrm{O}_{2}$ tension. Proc Nat Acad Sci USA 92:5510-5514

2. Wang GL, Semenza GL 1995 Purification and characterization of hypoxia-inducible factor 1. J Biol Chem 270:1230-1237

3. Salceda S, Caro J 1997 Hypoxia-inducible factor $1 \alpha$ (HIF-1 $\alpha$ ) protein is rapidly degraded by the ubiquitin-proteasome system under normoxic conditions: its stabilization by hypoxia depends upon redox-induced changes. J Biol Chem 272:2264222647

4. Sutter CH, Laughner E, Semenza GL 2000 Hypoxia-inducible factor $1 \alpha$ protein expression is controlled by oxygen-regulated ubiquitination that is disrupted by deletions and missense mutations. Proc Natl Acad Sci USA 97:4748-4753

5. Jiang B-H, Zheng JZ, Leung SW, Roe R, Semenza GL 1997 Transactivation and inhibitory domains of hypoxia-inducible factor $1 \alpha$ : modulation of transcriptional activity by oxygen tension. J Biol Chem 272:19253-19260

6. Pugh CW, O'Rourke JF, Nagao M, Gleadle JM, Ratcliffe PJ 1997 Activation of hypoxia-inducible factor-1; definition of regulatory domains within the $\alpha$ subunit. J Biol Chem 272:11205-11214

7. Iyer NV, Kotch LE, Agani F, Leung SW, Laughner E, Wenger RH, Gassmann M, Gearhart JD, Lawler AM, Yu AY, Semenza GL 1998 Cellular and developmental control of $\mathrm{O}_{2}$ homeostasis by hypoxia-inducible factor $1 \alpha$. Genes Dev 12:149-162

8. Kotch LE, Iyer NV, Laughner E, Semenza GL 1999 Defective vascularization of HIF-1 $\alpha$-null embryos is not associated with VEGF deficiency but with mesenchymal cell death. Dev Biol 209:254-267

9. Ryan HE, Lo J, Johnson RS 1998 HIF-1 $\alpha$ is required for solid tumor formation and embryonic vascularization. EMBO J 17:3005-3015 
10. Yu AY, Shimoda LA, Iyer NV, Huso DL, Sun X, McWilliams R, Beaty T, Sham JSK Wiener CM, Sylvester JT, Semenza GL 1999 Impaired physiological responses to chronic hypoxia in mice partially deficient for hypoxia-inducible factor $1 \alpha$. J Clin Invest 103:691-696

11. Carmeliet P, Dor Y, Herbert J-M, Fukumura D, Brusselmans K, Dewerchin M, Neeman M, Bono F, Abramovitch R, Maxwell P, Koch CJ, Ratcliffe P, Moons L, Jain RK, Collen D, Keshet E 1998 Role of HIF-1 $\alpha$ in hypoxia-mediated apoptosis, cell proliferation, and tumour angiogenesis. Nature 394:485-490

12. Martin C, Yu AY, Jiang BH, Davis L, Kimberly D, Hohimer AR, Semenza GL 1998 Cardiac hypertrophy in chronically anemic fetal sheep: increased vascularization is associated with increased myocardial expression of vascular endothelial growth factor and hypoxia-inducible factor 1. Am J Obstet Gynecol 178:527-534

13. Frenkel-Denkberg G, Gershon D, Levy AP 1999 The function of hypoxia-inducible factor 1 (HIF-1) is impaired in senescent mice. FEBS Lett 462:341-344

14. Rivard A, Fabre JE, Silver M, Chen D, Murohara T, Kearney M, Magner M, Asahara T, Isner JM 1999 Age-dependent impairment of angiogenesis. Circulation 99:111 120

15. Rivard A, Berthou-Soulie L, Principe N, Kearney M, Curry C, Branellec D, Semenza GL, Isner JM 2000 ge-dependent defect in VEGF expression is associated with reduced HIF-1 activity. J Biol Chem 275:29643-29647

16. Vincent KA, Shyu, K-G, Luo Y, Magner M, Tio RA, Jiang C, Goldberg MA, Akita GY, Gregory RJ, Isner JM 2000 Angiogenesis is induced in a rabbit model of hindlimb ischemia by naked DNA encoding a HIF- $1 \alpha / \mathrm{VP}-16$ hybrid transcription factor. Circulation 102:2255-2261

17. Ozaki H, Yu AY, Della N, Ozaki K, Luna JD, Yamada H, Hackett SF, Okamoto N, Zack DJ, Semenza GL, Campochiaro PA 1999 Hypoxia-inducible factor $1 \alpha$ is increased in ischemic retina: temporal and spatial correlation with VEGF expression. Invest Ophthalmol Vis Sci 40:182-189

18. Stone J, Itin A, Alon T, Pe'er J, Gnessin H, Chan-Ling T, Keshet E 1995 Development of retinal vasculature is mediated by hypoxia-induced vascular endothelial growth factor (VEGF) expression by neuroglia. J Neurosci 15:4738-4747

19. Pierce EA, Avery RL, Foley ED, Aiello LP, Smith LE 1995 Vascular endothelia growth factor/vascular permeability factor expression in a mouse model of retinal neovascularization. Proc Natl Acad Sci USA 92:905-909

20. Aiello LP, Pierce EA, Foley ED, Takagi H, Chen H, Riddle L, Ferrara N, King GL, Smith LE 1995 Suppression of retinal neovascularization in vivo by inhibition of vascular endothelial growth factor (VEGF) using soluble VEGF-receptor chimeric proteins. Proc Natl Acad Sci USA 92:10457-10461

21. Gidday JM, Fitzgibbons JC, Shah AR, Park TS 1994 Neuroprotection from ischemic brain injury by hypoxic preconditioning in the neonatal rat. Neurosci Lett 168:221224

22. Bergeron M, Gidday JM, Yu AY, Semenza GL, Ferriero DM, Sharp FR 2000 Role of hypoxia-inducible factor 1 (HIF-1) in hypoxia-induced ischemic tolerance in neonatal rat brain. Ann Neurol 48:285-296

23. Wang GL, Semenza GL 1993 Desferrioxamine induces erythropoietin gene expression and hypoxia-inducible factor 1 DNA binding activity: implications for models of hypoxia signal transduction. Blood 82:3610-3615

24. Hayashi T, Abe K, Itoyama Y 1998 Reduction of ischemic damage by application of vascular endothelial growth factor in rat brain after transient ischemia. J Cereb Blood Flow Metab 18:887-895

25. Sakanaka M, Wen TC, Matsuda S, Masuda S, Morishita E, Nagao M, Sasaki R 1998 In vivo evidence that erythropoietin protects neurons from ischemic damage. Proc Natl Acad Sci USA 95:4635-4640

26. Bergeron M, Yu AY, Solway K, Semenza GL, Sharp FR 1999 Induction of hypoxiainducible factor-1 (HIF-1) and its target genes following focal ischemia in rat brain. Eur J Neurosci 11:1-12

27. Halterman MW, Miller CC, Federoff HJ 1999 Hypoxia-inducible factor- $1 \alpha$ mediates hypoxia-induced delayed neuronal death that involves $\mathrm{p} 53$. J Neurosci 19:6818-682

28. An WG, Kanekal M, Simon MC, Maltepe E, Blagosklonny MV, Neckers LM 1998 Stabilization of wild-type p53 by hypoxia-inducible factor $1 \alpha$. Nature 392:405-408

29. Banasiak KJ, Haddad GG 1998 Hypoxia-induced apoptosis: effect of hypoxic severity and role of p53 in neuronal cell death. Brain Res 797:295-304

30. Semenza GL 2000 Hypoxia, clonal selection, and the role of HIF-1 in tumor progression. Crit Rev Biochem Mol Biol 35:71-103

31. Zagzag D, Zhong H, Scalzitti JM, Laughner E, Simons JW, Semenza GL 2000 Expression of hypoxia-inducible factor $1 \alpha$ in human brain tumors: association with angiogenesis, invasion, and progression. Cancer 88:2606-2618

32. Zhong H, De Marzo AM, Laughner E, Lim M, Hilton DA, Zagzag D, Buechler P, Isaacs WB, Semenza GL, Simons JW 1999 Overexpression of hypoxia-inducible factor $1 \alpha$ in common human cancers and their metastases. Cancer Res 59:5830-5835

33. Graeber TG, Osmanian C, Jacks T, Housman DE, Koch CJ, Lowe SW, Giaccia A 1996 Hypoxia-mediated selection of cells with diminished apoptotic potential in solid tumors. Nature 379:88-91

34. Haupt Y, Maya R, Kazaz A, Oren M 1997 Mdm2 promotes the rapid degradation of p53. Nature 387:296-299

35. Kubbutat MHG, Jones SN, Vousden KH 1997 Regulation of p53 stability by Mdm2. Nature 387:299-303

36. Ravi R, Mookerjee B, Bhujwalla ZM, Sutter CH, Artemov D, Zeng Q, Dillehay LE, Madan A, Semenza GL, Bedi A 2000 Regulation of tumor angiogenesis by p53induced degradation of hypoxia-inducible factor $1 \alpha$. Genes Dev 14:34-44

37. Cockman ME, Masson N, Mole DR, Jaakkola P, Chang GW, Clifford SC, Maher ER, Pugh CW, Ratcliffe PJ, Maxwell PH 2000 Hypoxia inducible factor- $\alpha$ binding and ubiquitylation by the von Hippel-Lindau tumor suppressor protein. J Biol Chem 275:25733-25741

38. Maxwell PH, Wiesener MS, Chang GW, Clifford SC, Vaux EC, Cockman ME, Wykoff CC, Pugh CW, Maher ER, Ratcliffe PJ 1999 The tumour suppressor protein
VHL targets hypoxia-inducible factors for oxygen-dependent proteolysis. Nature 399:271-275

39. Caniggia I, Mostachfi H, Winter J, Gassmann M, Lye SJ, Kuliszewski M, Post M 2000 Hypoxia-inducible factor- 1 mediates the biological effects of oxygen on human trophoblast differentiation through TGF $\beta_{3}$. J Clin Invest 105:577-587

40. Tazuke SI, Mazure NM, Sugawara J, Carland G, Faessen GH, Suen L-F, Irwin JC, Powell DR, Giaccia AJ, Giudice LC 1998 Hypoxia stimulates insulin-like growth factor binding protein 1 (IGFBP-1) gene expression in HepG2 cells: a possible model for IGFBP-1 expression in fetal hypoxia. Proc Natl Acad Sci USA 95:10188-10193

41. Wood SM, Wiesener MS, Yeates KM, Okada N, Pugh CW, Maxwell PH, Ratcliffe PJ 1998 Selection and analysis of a mutant cell line defective in the hypoxia-inducible factor-1a-subunit (HIF-1a): characterization of HIF-1 $\alpha$-dependent and independent hypoxia-inducible gene expression. J Biol Chem 273:8360-8368

42. Eckhart AD, Yang N, Xin X, Faber JE 1997 Characterization of the $\alpha 1_{\mathrm{B}}$-adrenergic receptor gene promoter region and hypoxia regulatory elements in vascular smooth muscle. Proc Natl Acad Sci USA 94:9487-9492

43. Cormier-Regard S, Nguyen SV, Claycomb WC 1998 Adrenomedullin gene expression is developmentally regulated and induced by hypoxia in rat ventricular cardiac myocytes. J Biol Chem 273:17787-17792

44. Mukhopadhyay CK, Mazumder B, Fox PL 2000 Role of hypoxia-inducible factor 1 in transcriptional activation of ceruloplasmin by iron deficiency. J Biol Chem $275: 21048-21054$

45. Hu J, Discher DJ, Bishopric NH, Webster KA 1998 Hypoxia regulates expression of the endothelin-1 gene through a proximal hypoxia-inducible factor-1 binding site on the antisense strand. Biochem Biophys Res Commun 245:894-899

46. Jiang B-H, Rue E, Wang GL, Roe R, Semenza GL 1996 Dimerization, DNA binding, and transactivation properties of hypoxia-inducible factor 1. J Biol Chem 271:1777117778

47. Lee PJ, Jiang B-H, Chin BY, Iyer NV, Alam J, Semenza GL, Choi AMK 1997 Hypoxia-inducible factor 1 mediates transcriptional activation of the heme oxygenase-1 gene in response to hypoxia. J Biol Chem 272:5375-5381

48. Feldser D, Agani F, Iyer NV, Pak B, Ferreira G, Semenza GL 1999 Reciprocal positive regulation of hypoxia-inducible factor 1a and insulin-like growth factor 2 . Cancer Res 59:3915-3918

49. Melillo G, Musso T, Sica A, Taylor LS, Cox GW, Varesio L 1995 A hypoxiaresponsive element mediates a novel pathway of activation of the inducible nitric oxide synthase promoter. J Exp Med 182:1683-1693

50. Palmer LA, Semenza GL, Stoler MH, Johns RA 1998 Hypoxia induces type II NOS gene expression in pulmonary artery endothelial cells via HIF-1. Am J Physiol 274:L212-L219

51. Bhattacharya S, Michels CL, Leung MK, Arany ZP, Kung AL, Livingston DM 1999 Functional role of $\mathrm{p} 35 \mathrm{srj}$, a novel $\mathrm{p} 300 / \mathrm{CBP}$ binding protein, during transactivation by HIF-1. Genes Dev 13:64-75

52. Kietzmann T, Roth U, Jungermann K 1999 Induction of the plasminogen activator inhibitor-1 gene expression by mild hypoxia via a hypoxia response element binding the hypoxia-inducible factor-1 in rat hepatocytes. Blood 94:4177-4185

53. Takahashi Y, Takahashi S, Shiga Y, Yoshimi T, Miura T 2000 Hypoxic induction of prolyl 4-hydroxylase alpha (I) in cultured cells. J Biol Chem 275:14139-14146

54. Rolfs A, Kvietikova I, Gassmann M, Wenger RH 1997 Oxygen-regulated transferrin expression is mediated by hypoxia-inducible factor-1. J Biol Chem 272:20055-20562

55. Lok CN, Ponka P 1999 Identification of a hypoxia response element in the transferrin receptor gene. J Biol Chem 274:24147-24152

56. Tacchini L, Bianchi L, Bernelli-Zazzera A, Cairo G 1999 Transferrin receptor induction by hypoxia: HIF-1-mediated transcriptional activation and cell-specific post-transcriptional regulation. J Biol Chem 274:24142-24146

57. Gerber H-P, Condorelli F, Park J, Ferrara N 1997 Differential transcriptional regulation of the two vascular endothelial growth factor receptor genes: Flt-1, but not Flk-1/KDR, is upregulated by hypoxia. J Biol Chem 272:23659-23667

58. Zhong H, Chiles K, Feldser D, Laughner E, Hanrahan C, Georgescu M-M, Simons JW, Semenza GL 2000 Modulation of HIF-1 $\alpha$ expression by the epidermal growth factor/phosphatidylinositol 3-kinase/PTEN/AKT/FRAP pathway in human prostate cancer cells: implications for tumor angiogenesis and therapeutics. Cancer Res 60:1541-1545

59. Zundel W, Schindler C, Haas-Kogan D, Koong A, Kaper F, Chen E, Gottschalk AR, Ryan HE, Johnson RS, Jefferson AB, Stokoe D, Giaccia AJ 2000 Loss of PTEN facilitates HIF-1-mediated gene expression. Genes Dev 14: 391-396

60. Minet E, Arnould T, Michel G, Roland D, Mottet D, Raes M, Remacle J, Michiels C 2000 ERK activation upon hypoxia: involvement in HIF-1 activation. FEBS Lett 484:53-58

61. Richard DE, Berra E, Gothie E, Roux D, Pouyssegur J 1999 p42/p44 mitogenactivated protein kinases phosphorylate hypoxia-inducible factor $1 \alpha(\mathrm{HIF}-1 \alpha)$ and enhance the transcriptional activity of HIF-1. J Biol Chem 274:32631-32637

62. Mazure NM, Chen EY, Laderoute KR, Giaccia AJ 1997 Induction of vascular endothelial growth factor by hypoxia is modulated by a phosphatidylinositol 3-kinase/ Akt signaling pathway in Ha-ras-transformed cells through a hypoxia inducible factor-1 transcriptional element. Blood 90:3322-3331

63. Jiang B-H, Agani F, Passaniti A, Semenza GL 1997 V-SRC induces expression of hypoxia-inducible factor 1 (HIF-1) and transcription of genes encoding vascular endothelial growth factor and enolase 1: involvement of HIF-1 in tumor progression. Cancer Res 57:5328-5335

64. Agani F, Semenza GL 1998 Mersalyl is a novel inducer of vascular endothelial growth factor gene expression and hypoxia-inducible factor 1 activity. Mol Pharmacol 54:749-754

65. Zelzer E, Levy Y, Kahana C, Shilo B-Z, Rubinstein M, Cohen B 1998 Insulin induces transcription of target genes through the hypoxia-inducible factor HIF-1 $\alpha /$ ARNT. EMBO J 17:5085-5094 